\title{
Alcohol consumption in patients with nonalcoholic fatty liver disease: yes, or no?
}

\section{Adonis A. Protopapas ${ }^{a}$, Evangelos Cholongitas ${ }^{b}$, Lampros Chrysavgis ${ }^{b}$, Konstantinos Tziomalos ${ }^{a}$}

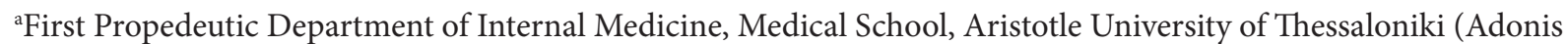

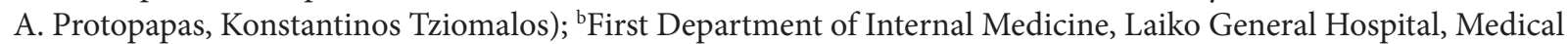
School, National and Kapodistrian University of Athens (Evangelos Cholongitas, Lampros Chrysavgis), Greece

Abstract

\begin{abstract}
Excessive alcohol intake is an established risk factor for chronic liver disease. At the same time, moderate alcohol intake appears to reduce cardiovascular morbidity. Accordingly, recommendations for alcohol intake in patients with nonalcoholic fatty liver disease (NAFLD), who are at increased risk for liver-related and cardiovascular events, are a point of debate. Some studies have shown beneficial effects of alcohol on cardiovascular and overall mortality in this specific subset of patients. Nonetheless, even light alcohol intake appears to aggravate liver disease and increase the risk of hepatocellular cancer. Therefore, patients with nonalcoholic steatohepatitis or advanced fibrosis should be advised against consuming alcohol. On the other hand, only light alcohol consumption $(<10 \mathrm{~g} /$ day) might be permitted in patients without significant hepatic fibrosis, provided that they are carefully followed-up. As the research field focusing on NAFLD keeps widening, more prospective studies regarding this specific subject are expected, and may provide a basis for less ambiguous recommendations.
\end{abstract}

Keywords Nonalcoholic fatty liver disease, alcohol, cardiovascular disease, hepatocellular cancer, fibrosis

Ann Gastroenterol 2021; 34 (X): 1-11

\section{Introduction}

Nonalcoholic fatty liver disease (NAFLD) is the most common chronic liver disease. It affects as many as one-fourth of the general population worldwide, being more frequent in patients with metabolic syndrome (MetS) or its components than in the general population [1]. NAFLD diagnosis requires that the patient does not exhibit daily alcohol consumption of $\geq 30 \mathrm{~g}$ for men or $\geq 20 \mathrm{~g}$ for women [2]. NAFLD can progress from isolated steatosis to nonalcoholic steatohepatitis (NASH), which encompasses, besides steatosis, ballooning hepatocellular injury, inflammation and liver fibrosis, and might evolve to cirrhosis or even to hepatocellular carcinoma (HCC) $[3,4]$.

Medical School, Aristotle University of Thessaloniki; Laiko General Hospital, Medical School, National and Kapodistrian University of Athens, Greece

\section{Conflict of Interest: None}

Correspondence to: Adonis A. Protopapas, First Propedeutic Department of Internal Medicine, Medical School, Aristotle University of Thessaloniki, AHEPA Hospital, 1 Stilponos Kyriakidi street, Thessaloniki, 54636, Greece, e-mail: adoprot@hotmail.com

Received 1 January 2021; accepted 3 March 2021; published online 3 June 2021

DOI: https://doi.org/10.20524/aog.2021.0641
Patients with NAFLD are at high risk for cardiovascular disease and are more likely to die from coronary heart disease than hepatic disease; indeed, cardiovascular disease is the most common cause of death in this population [5-7]. Modification of cardiovascular risk factors includes lifestyle interventions, such as regular physical exercise, and weight loss [8]. In addition, moderate alcohol consumption also appears to reduce the risk of coronary heart disease [9]. On the other hand, excessive alcohol consumption is an established risk factor for liver disease, with various cofactors influencing liver disease development in patients with excessive alcohol use (Fig. 1) [10-23]. However, accumulating data suggest that moderate alcohol intake might reduce NAFLD incidence [24]; the mechanisms possibly involved (studied in both animal and human models) are illustrated in Fig. 2 [25-31]. Taking these conflicting effects of alcohol into account, it is of great interest to elucidate the role of light and moderate alcohol consumption in NAFLD, in order to counsel these patients regarding alcohol use. There have been relatively recent reviews regarding the subject in question $[32,33]$, but because of the constant publication of new studies on the subject, many critical studies are not included in these reviews, which significantly alter prior beliefs regarding alcohol use in NAFLD. This narrative review aims to summarize recent developments in this field and encapsulate how these developments affect recommendations regarding alcohol consumption in NAFLD. 


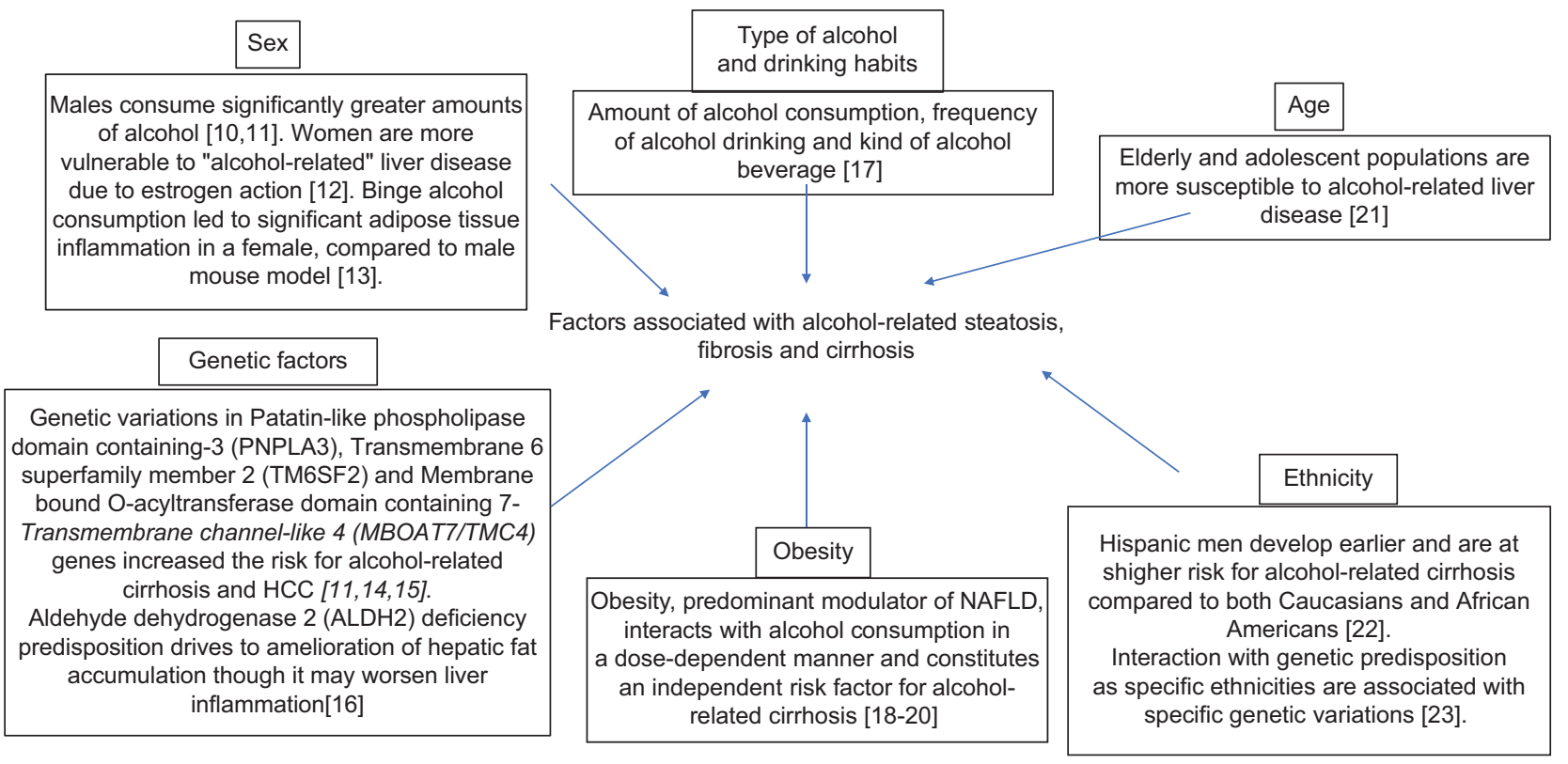

Figure 1 Individual phenotypic and genetic factors associated with alcohol-induced liver steatosis, fibrosis and cirrhosis NAFLD, nonalcoholic fatty liver disease; HCC, hepatocellular carcinoma
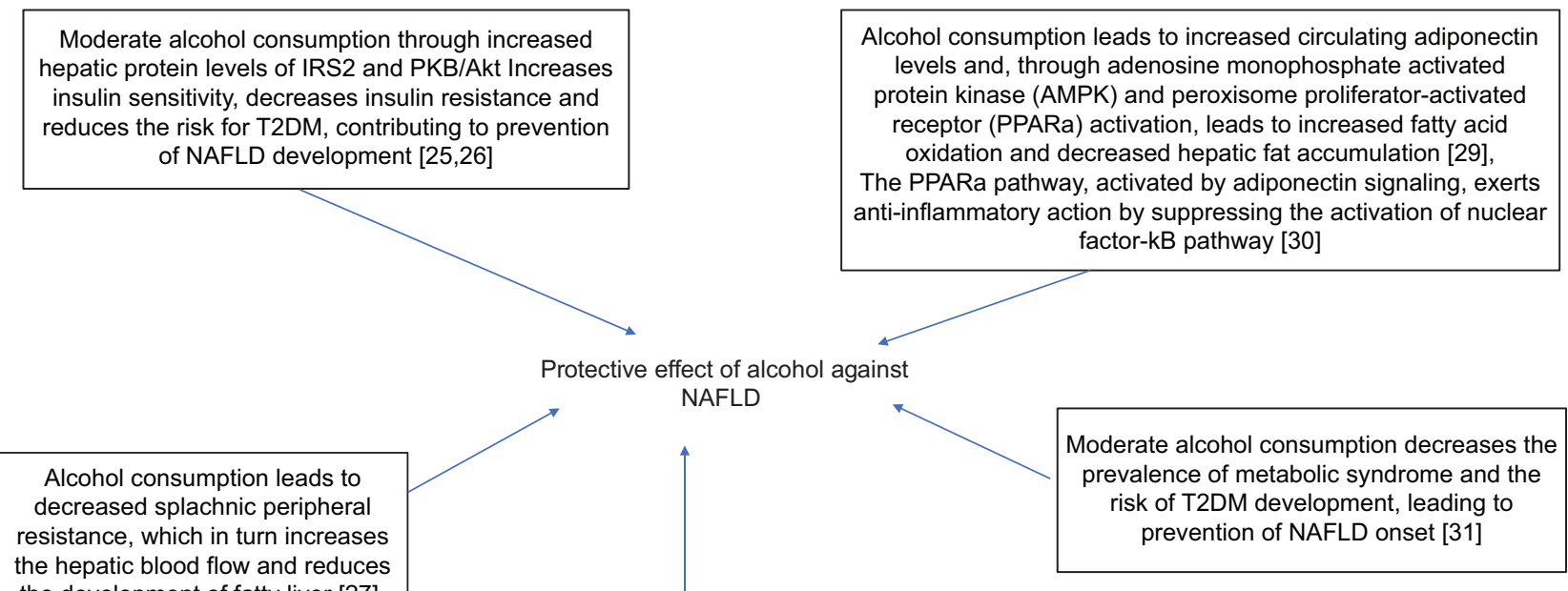

Alcohol consumption leads to decreased splachnic peripheral resistance, which in turn increases the hepatic blood flow and reduces the development of fatty liver [27].

Protective effect of alcohol agains

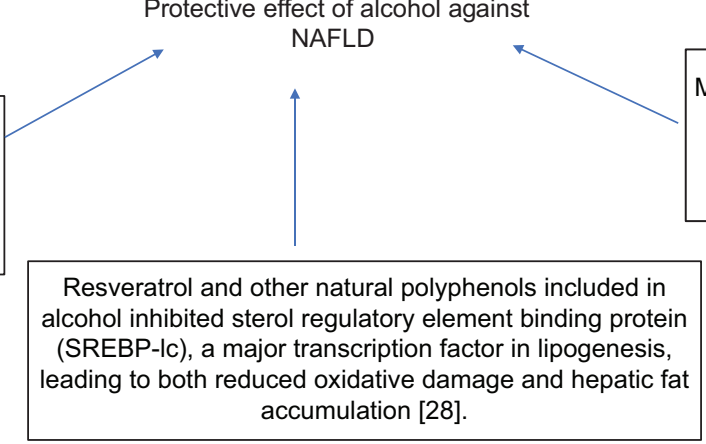

Figure 2 Mechanisms of the beneficial impact of moderate alcohol consumption on NAFLD development NAFLD, nonalcoholic fatty liver disease; T2DM, type 2 diabetes mellitus

\section{Literature search}

To find relevant studies, we conducted a thorough search in the PubMed, Google Scholar and Cochrane Library databases through December 2020. Search terms included "NAFLD", "non-alcoholic fatty liver disease", "hepatic steatosis", "fatty liver", "alcohol", and "ethanol". We also searched the references of selected studies and relevant reviews for unidentified studies. The studies that were included analyzed outcomes in patients with NAFLD (or NAFLD incidence) with regard to levels of alcohol consumption.

\section{Does alcohol prevent the development of fatty liver?}

The common histopathological features shared between NAFLD and alcoholic liver disease (ALD) [34], as well as the 
fact that one is frequently misclassified as the other [35], can be partially explained by the shared mechanisms contributing to the emergence of both diseases [36,37]. However, only one study showed that alcohol consumption increases the risk of NAFLD. Long et al evaluated the correlation between the presence of hepatic steatosis (assessed by computed tomography) and alcohol consumption in 2475 participants of the Framingham study [38], after excluding heavy drinkers. The number of alcoholic drinks consumed per week was an independent predictor of steatosis (odds ratio [OR] 1.15, 95\% confidence interval [CI] 1.02-1.29.

In contrast, several studies support the notion that moderate alcohol consumption can have a protective effect against NAFLD development. In a large study, Hashimoto et al evaluated 5437 healthy Japanese individuals on a regular checkup program for over a decade [39]. The hazard ratios (HR) for newly diagnosed fatty liver in subjects with light (40-140 g/week) and moderate (140-280 g/week) alcohol consumption compared with those with no or minimal alcohol consumption $(<40 \mathrm{~g} /$ week $)$ were $0.72,95 \%$ CI $0.60-0.86$, and $0.69,95 \%$ CI $0.57-0.84(\mathrm{P}<0.001)$, respectively, in men. In women, alcohol consumption was not associated with the incidence of NAFLD. Another study in Japanese men reported similar findings; light (40-140 g/week) and moderate alcohol intake (140-280 g/week) were associated with a reduced risk for fatty liver development, compared to null drinking consumption (OR 0.82, 95\%CI 0.68-0.99 and $0.75,95 \%$ CI $0.61-0.93$, respectively) [40]. Interestingly, Hiramine et al showed that not only light $(<20$ g/day, OR 0.71 , 95\%CI 0.59-0.86) and moderate (20-60 g/day, OR 0.55, 95\%CI $0.45-0.67$ ), but also heavy (>60 g/day, OR $0.44,95 \% \mathrm{CI} 0.32-$ 0.62 ) alcohol drinking was associated with decreased odds for fatty liver compared to non-drinkers in Japanese men [41], confirmed by another study from Asia [42]. In accordance with the studies mentioned above, Hamaguchi et al performed a cross-sectional study on 18,571 Japanese individuals. They reported that any level of alcohol consumptionlight (40-140 g/week, OR 0.69, 95\%CI 0.6-0.79), moderate (140-280 g/week, OR 0.72, 95\%CI 0.63-0.83) and excessive (>280 g/week, OR 0.74, 95\%CI 0.64-0.85) compared with no or minimal ( $<40 \mathrm{~g} /$ week) was associated with decreased odds for fatty liver in men. In contrast, in women, light (OR 0.54, 95\%CI 0.34-0.88) and moderate (OR 0.43, 95\%CI 0.21-0.88) alcohol intake decreased the likelihood of the presence of fatty liver [43]. Finally, a recent study by Chang et al showed that light (<10 g/day) and moderate (10-20 g/day) drinking were independently associated with a lower incidence of NAFLD compared to non-drinkers (HR 0.93, 95\%CI 0.90-0.95, and HR 0.90, 95\%CI 0.87-0.92, respectively) [44]. However, light and moderate drinkers were more susceptible to developing NAFLD with significant fibrosis (FIB-4 >1.3) compared to non-drinkers (HR 1.15, 95\%CI 1.04-1.27, and HR 1.49, 95\%CI 1.33-1.66, respectively).

Several studies also suggest that more frequent alcohol consumption might also decrease the risk of NAFLD. Hiramine et al [41] reported that the prevalence of fatty liver was negatively correlated with alcohol drinking (OR 0.62, 95\%CI $0.53-0.71$ for $\geq 21$ days/month vs. $\leq 10$ days/month). Similarly, in the cross-sectional study by Moriya et al, an inverse association between the prevalence of fatty liver and alcohol consumption frequency was observed in men [45]. In women, drinking $<20$ g alcohol during 1-3 days/week was also associated with a reduced prevalence of fatty liver [45]. A longitudinal study from the same group in 5297 Japanese individuals showed that the frequency of alcohol consumption was inversely associated with fatty liver in men (OR $0.81,95 \%$ CI $0.71-0.93$, OR 0.68 , 95\%CI 0.58-0.78, and OR 0.64, 95\%CI 0.56-0.73, for $1-3$ days/ week, 4-6 days/week and daily, respectively); in women, daily alcohol consumption was also associated with a lower incidence of fatty liver (OR 0.60, 95\%CI 0.40-0.90) [46]. In another study from Japan, Sogabe et al assessed 1055 men with MetS and NAFLD and reported that the prevalence of NAFLD was lower in light drinkers (consuming $<20 \mathrm{~g}$ of alcohol/drinking day) than in non-drinkers [47]. Finally, a meta-analysis by Sookoian et al confirmed the findings of previous studies, showing that moderate consumption $(<40 \mathrm{~g} /$ day $)$ was associated with lower odds of NAFLD (OR 0.68, 95\%CI 0.58-0.81) and NASH (OR 0.5, 95\%CI 0.34-0.74) development, compared to nondrinkers [48].

It should be emphasized that most of the studies that evaluated the impact of alcohol consumption on the incidence of fatty liver were performed in Asian and mostly Japanese populations. Therefore, the generalizability of their findings in non-Asian subjects is an open question. Also, it should be noted that many of these studies use definitions of moderate alcohol consumption that are nowadays considered to be equivalent to alcohol-related liver disease. Studies investigating the effect of alcohol consumption on the development of NAFLD are summarized in Table 1.

\section{Is alcohol associated with less severe histological lesions in NAFLD patients?}

To evaluate the impact of alcohol consumption on the severity of hepatic fibrosis in patients with NAFLD, Hagström et al prospectively studied 120 patients with biopsy-proven NAFLD and evaluated their lifetime alcohol use using questionnaires [49]. After adjusting for physical activity, and soft drink and coffee consumption, the odds for severe fibrosis decreased for each additional alcohol unit consumed (i.e., 12 grams of alcohol) for up to a maximum of 13 drinks/week (OR 0.86 , 95\%CI 0.76-0.97); moreover, subjects in the top quartile of alcohol consumption (3.1-13.3 alcohol units/week) had the lowest risk for severe fibrosis (OR 0.23 , 95\%CI 0.08-0.66). Furthermore, patients who consumed alcohol more than the median (1.1 units of alcohol/week) had lower levels of markers of subclinical inflammation (tumor necrosis factor and highsensitivity C-reactive protein) and higher total cholesterol levels compared with those who consumed lower amounts of alcohol [49]. In accordance with these findings, a study from the USA in 77 patients with histologically confirmed NAFLD showed that those with overall lifetime alcohol use $\geq 24$ gramyears had less advanced fibrosis, lower percent total body fat and lower total cholesterol levels compared with those who had consumed $<24$ gram-years of alcohol [50]. Gram-years were 
Table 1 Studies investigating the effect of alcohol consumption on the development of NAFLD

\begin{tabular}{|c|c|c|c|}
\hline $\begin{array}{l}\text { Study/ year/ } \\
\text { country/ type }\end{array}$ & $\begin{array}{l}\text { Study population/ } \\
\text { NAFLD diagnosis }\end{array}$ & $\begin{array}{l}\text { Outcome: Development of NAFLD (statistically significant } \\
\text { correlations) }\end{array}$ & Comments \\
\hline $\begin{array}{l}\text { Long et al [38] } \\
2019 \text { / USA } \\
\text { Cross- } \\
\text { sectional }\end{array}$ & $\begin{array}{l}\text { - } 2475 \text { participants of the } \\
\text { Framingham study } \\
\text { - Computed tomography }\end{array}$ & $\begin{array}{l}\text { - Alcohol consumption (drinks/week) independently correlated } \\
\text { with the development of liver steatosis } \\
\text { - Binge drinking was independently associated with presence of steatosis } \\
\text { - Wine consumption was not associated with steatosis }\end{array}$ & $\begin{array}{l}\text { - Exclusion of heavy drinkers } \\
\text { ( }>14 \text { or }>21 \text { drinks/week } \\
\text { for women and men } \\
\text { respectively) }\end{array}$ \\
\hline $\begin{array}{l}\text { Hashimoto } \\
\text { et al [39] } \\
2015 \text { / Japan } \\
\text { Longitudinal }\end{array}$ & $\begin{array}{l}\text { - } 5437 \text { healthy subjects } \\
\text { undergoing repeated } \\
\text { health checkups } \\
\text { - Abdominal ultrasound }\end{array}$ & $\begin{array}{l}\text { - Light ( } 40-140 \mathrm{~g} / \text { week) and moderate }(140-280 \mathrm{~g} / \text { week }) \\
\text { alcohol consumption vs. minimal or no }(<40 \mathrm{~g} / \text { week) alcohol } \\
\text { consumption (HR } 0.72 \text { [95\%CI 0.60-0.86] and } 0.69 \text { [95\%CI 0.57- } \\
\text { 0.84] respectively) }\end{array}$ & $\begin{array}{l}\text { - High alcohol thresholds for } \\
\text { moderate drinkers } \\
\text { - Results were significant } \\
\text { only for men }\end{array}$ \\
\hline $\begin{array}{l}\text { Gunji et al }[40] \\
2009 / \text { Japan } \\
\text { Cross- } \\
\text { sectional }\end{array}$ & $\begin{array}{l}\text { - } 5599 \text { men having a } \\
\text { health checkup } \\
\text { - Abdominal ultrasound }\end{array}$ & $\begin{array}{l}\text { - Light ( } 40-140 \mathrm{~g} / \text { week) and moderate }(140-280 \mathrm{~g} / \text { week }) \text { alcohol } \\
\text { intake vs. abstinence }(<40 \mathrm{~g} / \text { week) (OR } 0.82 \text { [95\%CI 0.68-0.99] } \\
\text { and } 0.75 \text { [95\%CI 0.61-0.93], respectively) }\end{array}$ & $\begin{array}{l}\text { - High alcohol thresholds for } \\
\text { moderate drinkers }\end{array}$ \\
\hline $\begin{array}{l}\text { Hiramine et al } \\
{[41]} \\
2011 \text { / Japan } \\
\text { Cross- } \\
\text { sectional }\end{array}$ & $\begin{array}{l}\text { - } 9886 \text { men undergoing } \\
\text { a health checkup, aged } \\
30-69 \text { years } \\
\text { - Abdominal ultrasound }\end{array}$ & $\begin{array}{l}\text { - Light }(<20 \mathrm{~g} / \text { day), moderate }(20-60 \mathrm{~g} / \text { day }) \text { and heavy }(>60 \mathrm{~g} / \text { day }) \\
\text { vs. non-drinkers }(\mathrm{OR} 0.71[95 \% \mathrm{CI} 0.59-0.86], 0.55 \text { [95\%CI } 0.45- \\
0.67] \text { and } 0.44[95 \% \mathrm{CI} 0.32-0.62] \text {, respectively) } \\
\text { - Frequent ( }>21 \text { days/month) vs rare consumption ( }<10 \text { days/ } \\
\text { month) (OR } 0.62[95 \% \mathrm{CI} 0.54-0.71])\end{array}$ & $\begin{array}{l}\text { esholds for } \\
\text { es }\end{array}$ \\
\hline $\begin{array}{l}\text { Yamada et al } \\
{[42]} \\
2010 / \text { Japan } \\
\text { Cross- } \\
\text { sectional and } \\
\text { longitudinal }\end{array}$ & $\begin{array}{l}\text { - } 12453 \text { ( } 5444 \text { male and } \\
4980 \text { female) healthy } \\
\text { subjects undergoing } \\
\text { health checkups in } \\
\text { 2002-2005 } \\
\text { - Abdominal ultrasound }\end{array}$ & $\begin{array}{l}\text { - Cross-sectional: moderate (one drink/day) and heavy ( } \geq 2 \text { drinks/ } \\
\text { day) alcohol intake vs. non-drinkers (OR } 0.58 \text { [ } 95 \% \mathrm{CI} 0.52- \\
0.63] / 0.57 \text { [ } 95 \% \mathrm{CI} 0.52-0.63] \text { for men and } 0.53 \text { [95\%CI } 0.43- \\
0.64] / 0.85 \text { [ } 95 \% \text { CI } 0.60-1.23 \text { ] for women) } \\
\text { - Longitudinal/ Men: daily moderate and heavy alcohol intake vs. } \\
\text { non-drinkers (OR } 0.72 \text { [95\%CI 0.58-0.89]/0.65 [95\%CI 0.50-0.85]) }\end{array}$ & $\begin{array}{l}\text { - Longitudinal study: Exclusion } \\
\text { of patients who had NAFLD } \\
\text { at the first checkup } \\
\text { - Non-significant results for } \\
\text { women in the longitudinal } \\
\text { study }\end{array}$ \\
\hline $\begin{array}{l}\text { Hamaguchi } \\
\text { et al [43] } \\
2012 \text { / Japan } \\
\text { Cross- } \\
\text { sectional }\end{array}$ & $\begin{array}{l}\text { - } 18571 \text { ( } 10982 \text { men and } \\
7589 \text { women) healthy } \\
\text { subjects undergoing a } \\
\text { health checkup } \\
\text { - Abdominal ultrasound }\end{array}$ & $\begin{array}{l}\text { - Light }(40-140 \mathrm{~g} / \text { week) and moderate }(140-280 \mathrm{~g} / \text { week) vs. minimal } \\
\text { or no (<40 g/week) alcohol consumption (OR 0.69 [95\%CI 0.6- } \\
0.79], 0.72 \text { [95\%CI 0.63-0.83] for men and } 0.54 \text { [ } 95 \% \text { CI } 0.34-0.88] \text {, } \\
0.43 \text { [ } 95 \% \text { CI } 0.21-0.88] \text { and for women, respectively) } \\
\text { - Men: Heavy vs. minimal or no alcohol consumption (OR } 0.74 \\
\text { [95\%CI 0.64-0.85]) }\end{array}$ & $\begin{array}{l}\text { - High alcohol thresholds for } \\
\text { moderate drinkers } \\
\text { - Alcohol consumption had } \\
\text { no significant effect on } \\
\text { the incidence of metabolic } \\
\text { syndrome }\end{array}$ \\
\hline $\begin{array}{l}\text { Chang et al } \\
{[44]} \\
2020 \text { / S. Korea } \\
\text { Retrospective }\end{array}$ & $\begin{array}{l}\text { - } 190048 \text { subjects without } \\
\text { NAFLD at baseline } \\
\text { - Abdominal ultrasound } \\
\text { - Median follow up: } 4.1 \\
\text { years }\end{array}$ & $\begin{array}{l}\text { - NAFLD: Light }(<10 \mathrm{~g} / \text { day }) \text {, moderate }(10-20 \mathrm{~g} / \text { day vs. non-drinkers } \\
\text { (HR 0.94 [95\%CI 0.90-0.95] and 0.90 [95\%CI 0.87-0.92], respectively) } \\
\text { - Significant fibrosis: Light }(<10 \mathrm{~g} / \text { day), moderate }(10-20 \mathrm{~g} / \text { day vs. } \\
\text { non-drinkers (HR } 1.15 \text { [95\%CI } 1.04-1.27] \text { and } 1.49 \text { [ } 95 \% \mathrm{CI} 1.33 \text { - } \\
\text { 1.66], respectively) }\end{array}$ & $\begin{array}{l}\text { - Significant fibrosis was } \\
\text { assessed with the use of FIB- } 4 \\
\text { - Low BMI of the study } \\
\text { population } \\
\text { (mean: } 22 \mathrm{~kg} / \mathrm{m}^{2} \text { ) }\end{array}$ \\
\hline $\begin{array}{l}\text { Moriya et al } \\
{[45]} \\
2011 / \text { Japan } \\
\text { Cross- } \\
\text { sectional }\end{array}$ & $\begin{array}{l}\text { - } 7112 \text { (4957 men and } \\
2155 \text { women) healthy } \\
\text { subjects undergoing a } \\
\text { health checkup } \\
\text { - Abdominal ultrasound }\end{array}$ & $\begin{array}{l}\text { - Men: Light ( }<70 \mathrm{~g} / \text { week), moderate }(70-140 \mathrm{~g} / \text { week), heavy ( } 140- \\
280 \mathrm{~g} / \text { week) and overt }(>280 \mathrm{~g} / \text { week) vs. no alcohol consumption } \\
\text { (OR 0.75 [95\%CI 0.60-0.94], 0.62 [95\%CI 0.49-0.77], } 0.50 \text { [95\%CI } \\
\text { 0.41-0.61] and 0.40 [95\%CI 0.32-0.49], respectively) } \\
\text { - Women: Light }(<70 \mathrm{~g} / \text { week) vs no alcohol consumption (OR } 0.72 \\
\text { [95\%CI 0.53-0.97]) }\end{array}$ & $\begin{array}{l}\text { - In men, increasing alcohol } \\
\text { consumption was associated } \\
\text { with a further decrease in } \\
\text { odds for NAFLD, while in } \\
\text { women, only light alcohol } \\
\text { consumption conferred a } \\
\text { benefit }\end{array}$ \\
\hline $\begin{array}{l}\text { Moriya et al } \\
\text { [46] } \\
2015 \text { / Japan } \\
\text { Longitudinal }\end{array}$ & $\begin{array}{l}\text { - } 5297 \text { ( } 3773 \text { men and } \\
1524 \text { women) healthy } \\
\text { subjects undergoing } \\
\text { repeated health } \\
\text { checkups in 2003-2006 } \\
\text { - Abdominal ultrasound }\end{array}$ & $\begin{array}{l}\text { - Men: Light ( }<70 \mathrm{~g} / \text { week), moderate }(70-140 \mathrm{~g} / \text { week), heavy ( } 140- \\
280 \mathrm{~g} / \text { week) and overt (>280 g/week) vs. no alcohol consumption } \\
\text { (OR 0.79 [95\%CI 0.68-0.90], 0.73 [95\%CI 0.63-0.84], 0.69 [95\%CI } \\
0.60-0.79] \text { and } 0.68 \text { [95\%CI 0.58-0.79], respectively) }\end{array}$ & $\begin{array}{l}\text { - In men, increasing } \\
\text { consumption was associated } \\
\text { with a decrease in odds for } \\
\text { NAFLD, while in women, } \\
\text { there was no significant } \\
\text { difference among all groups }\end{array}$ \\
\hline $\begin{array}{l}\text { Sogabe et al } \\
{[47]} \\
2015 \text { / Japan } \\
\text { Cross-sectional }\end{array}$ & $\begin{array}{l}\text { - } 1055 \text { men with } \\
\text { metabolic syndrome } \\
\text { - Abdominal ultrasound }\end{array}$ & $\begin{array}{l}\text { - Light (<20 g/day) alcohol consumption vs. non-drinkers (OR } 0.65 \\
\text { [95\%CI 0.47-0.91]) }\end{array}$ & $\begin{array}{l}\text { - Only analyzed patients with } \\
\text { light alcohol consumption } \\
(<20 \text { g/day })\end{array}$ \\
\hline $\begin{array}{l}\text { Sookoian et al } \\
\text { [48] } 2013 \text { / } \\
\text { Meta-Analysis }\end{array}$ & $\begin{array}{l}\text { Research on NAFLD } \\
\text { development: } 43175 \\
\text { patients } \\
\text { Research on NASH } \\
\text { development: } 822 \text { patients }\end{array}$ & $\begin{array}{l}\text { - Moderate consumption }(<40 \mathrm{~g} / \text { day) was associated with lower } \\
\text { odds of NAFLD (OR 0.68 [95\%CI 0.58-0.81]) and NASH (OR } 0.5 \\
\text { [95\%CI 0.34-0.74]) development, compared to non-drinkers }\end{array}$ & $\begin{array}{l}\text { - High alcohol thresholds for } \\
\text { moderate drinkers } \\
\text { - Significant heterogeneity } \\
\text { in NAFLD studies, none in } \\
\text { NASH studies }\end{array}$ \\
\hline
\end{tabular}

NAFLD, nonalcoholic fatty liver disease; OR, odds ratio; HR, hazard ratio; CI, confidence interval; NASH, nonalcoholic steatohepatitis 
calculated by multiplying the amount of alcohol consumed per day and consumption duration in years. Notably, patients still drinking alcohol or abstinent for $\leq 1$ year had lower fibrosis scores and total body fat percent than patients who abstained from alcohol for $>1$ year. Notably, in a cross-sectional study that included 582 patients with biopsy-proven NAFLD-331 modest drinkers ( $\leq 20 \mathrm{~g}$ of alcohol daily) and 251 lifetime non-drinkers-moderate drinkers, compared with nondrinkers, had lower odds of having steatohepatitis, fibrosis, hepatocellular ballooning and Mallory-Denk bodies on liver biopsy (OR 0.52, 95\%CI 0.36-0.76, OR 0.56, 95\%CI 0.41-0.78, OR 0.62 , 95\%CI $0.45-0.87$, and OR 0.65 , 95\%CI $0.43-0.98$, respectively) [51]. Consistently, a cross-sectional study from Australia reported that low ( $<20 \mathrm{~g} /$ week) and moderate (20$100 \mathrm{~g} /$ week) consumption was associated with a lower risk for diabetes mellitus (OR 0.18, 95\%CI 0.05-0.67), NASH (OR 0.35, $95 \%$ CI $0.12-1$ ) and Mallory bodies in liver biopsy (OR 0.16 , $95 \% \mathrm{CI} 0.03-0.76)$ compared to no consumption. However, after adjustment for diabetes or insulin resistance index, alcohol consumption's beneficial effect on NASH severity was not confirmed [52]. Finally, Mitchell et al reported that patients with NAFLD who consumed modest ( $<70 \mathrm{~g} /$ week) and moderate ( $\geq 70 \mathrm{~g} /$ week) amounts of alcohol, compared to lifetime non-drinkers, had lower ballooning and fibrosis scores [53]. Notably, only modest alcohol consumption was associated with lower odds for advanced fibrosis (OR 0.33, 95\%CI 0.14-0.78) after adjusting for age, diabetes, body mass index (BMI), homeostatic model assessment, sex, and overall lifetime alcohol consumption, whereas binge alcohol drinking was not associated with a lower fibrosis stage [53]. It should be mentioned that patients who consumed only wine, compared to lifetime non-consumers, had a lower fibrosis stage and risk for severe fibrosis (OR 0.20, 95\%CI 0.06-0.69), whereas this protective effect was not observed in exclusive beer drinkers.

Given the limitations of self-reported alcohol consumption, Sookoian et al used a genetic variant (rs1229984 A;G) in the alcohol dehydrogenase $(A D H 1 B)$ gene as a proxy of long-term alcohol exposure and evaluated its association with the severity of histological lesions in patients with NAFLD [54]. Carriers of this polymorphism were found to consume lower amounts of alcohol than non-carriers. In contrast to the aforementioned studies' findings, carriers of this polymorphism had less severe steatosis and inflammation than non-carriers, whereas the fibrosis stage did not differ between the 2 groups. Moreover, several studies reported that increased alcohol consumption is associated with liver disease progression in patients with NAFLD. Ekstedt et al evaluated 71 patients with NAFLD diagnosed by liver biopsy [55]. The authors divided the patients according to disease progression as having insignificant or significant changes in liver biopsy (significant defined as worsening of $\geq 2$ stages of fibrosis). After a mean follow up of 13.8 years, reported heavy episodic drinking was independently associated with significant liver biopsy changes. In another study, which included 285 patients with NASH diagnosed by liver biopsy, those who abstained from alcohol at baseline experienced more significant reductions in steatosis grade and aspartate aminotransferase (AST) levels compared to modest drinkers ( 1 or 2 drinks on a typical drinking day) after a mean follow up of 47 months, while modest drinkers also had lower odds of NASH resolution (OR 0.32, 95\%CI 0.11-0.92). Interestingly, when considering changes in drinking habits, consistent non-drinkers had a more pronounced reduction in steatosis grade and higher odds of NASH resolution compared to consistent modest drinkers [56]. In a large study in 58,927 Korean patients with NAFLD and low fibrosis scores-NAFLD fibrosis score (NFS), FIB-4 and AST-to-platelet ratio index (APRI) - followed-up for a median of 8.3 years, modest alcohol drinking (10-20 g/day) was independently associated with worsening of all noninvasive fibrosis scores (HR 1.29, 95\%CI 1.18-1.40, HR 1.31, 95\%CI 1.23-1.40, and HR 1.09, 95\%CI 1.01-1.19 for FIB-4, NFS and APRI, respectively). In addition, light alcohol consumption ( $0-10 \mathrm{~g} /$ day) was also independently associated with worsening of NFS (HR 1.09, 95\%CI 1.021.16) [57]. Finally, a study by Aberg et al evaluated the risk of advanced liver disease in 8345 Finnish patients with NAFLD diagnosed with the Fatty Liver Index with respect to their drinking habits. Patients with alcohol consumption $>10$ g/day were more susceptible to developing advanced liver disease and the HR was dose-dependent (10-19 g, HR 2.18, 95\%CI 1.054.53; 20-29 g, HR 3.62, 95\%CI 1.69-7.76) [58]. Interestingly, this correlation was not significant in patients drinking mainly wine in amounts $<25 \mathrm{~g} /$ day.

Studies in this section are divided into 2 groups: studies investigating the effect of alcohol consumption on NAFLD severity at diagnosis, and studies investigating alcohol consumption on NAFLD progression. The latter studies provide more trust-worthy data because of the patients' follow up and share an identical conclusion: even modest consumption $(>10$ $\mathrm{g} /$ day) is tied to worse liver-related outcomes. However, light consumption ( $<10 \mathrm{~g} /$ day $)$ was not associated with worse liverrelated outcomes in most studies and was associated with lower odds for significant fibrosis in most studies investigating disease severity at diagnosis. Studies evaluating the effect of alcohol on the severity of hepatic disease in NAFLD are outlined in Table 2 .

\section{Does alcohol consumption increase the incidence of cancer in patients with NAFLD?}

In the study mentioned above by Alberg et al, the association between alcohol intake and cancer was also evaluated [58]. Patients with high alcohol consumption ( $>30 \mathrm{~g} /$ day) were more likely to be diagnosed with any malignancy, whereas those with low or moderate alcohol consumption ( $<30 \mathrm{~g} /$ day) showed no increased risk for malignancies. Others assessed whether alcohol affects the risk of HCC in patients with NAFLD. Ascha et al evaluated the risk of HCC in 195 patients with NASH-related cirrhosis [59]. During a median follow up of 3.2 years, any alcohol use and even social alcohol intake were independently associated with an increased risk of HCC compared with nondrinkers. These results were reinforced by a study by Kimura et al, which evaluated the occurrence of HCC in 301 patients with biopsy-proven NAFLD [60]. During a follow up of 6 
Table 2 Studies investigating the effect of alcohol consumption on the severity of hepatic disease in NAFLD

\begin{tabular}{|c|c|c|c|}
\hline $\begin{array}{l}\text { Study/ year/ } \\
\text { country / type }\end{array}$ & $\begin{array}{l}\text { Study } \\
\text { population }\end{array}$ & Liver-related outcomes & Comments \\
\hline $\begin{array}{l}\text { Hagstrom et al } \\
{[49]} \\
2017 \text { / Sweden } \\
\text { Cross-sectional }\end{array}$ & $\begin{array}{l}\text { - } 120 \text { patients } \\
\text { with biopsy- } \\
\text { proven } \\
\text { NAFLD }\end{array}$ & $\begin{array}{l}\text { - Lifetime alcohol consumption (up to } 13 \text { units/week) } \\
\text { independently correlated with lower odds for severe fibrosis } \\
\text { (OR 0.86 [95\%CI 0.76-0.97] for each unit added) } \\
\text { - Consumption of 3.1-13.3 units/week had lower odds for severe } \\
\text { fibrosis compared to minimal or no consumption (0-0.3 units/ } \\
\text { week) (OR } 0.23 \text { [ } 95 \% \text { CI } 0.08-0.66] \text { ) } \\
\text { - Lower levels of tumor necrosis factor and high-sensitivity } \\
\text { C-reactive protein in patients that consumed }>1.1 \text { units/week }\end{array}$ & $\begin{array}{l}\text { - The biomarker phosphatidyl ethanol } \\
\text { (PEth) was used to avoid underreporting } \\
\text { of alcohol intake. Patients with PEth } \\
>0.3 \mu \mathrm{mol} / \mathrm{L} \text { were classified as consuming } \\
\text { more than moderate amounts of alcohol } \\
\text { and were excluded from the primary } \\
\text { analysis } \\
\text { - Exclusion of heavy drinkers } \\
\text { (>14 units/week) }\end{array}$ \\
\hline $\begin{array}{l}\text { Kwon et al [50] } \\
2014 \text { / USA } \\
\text { Cross-sectional }\end{array}$ & $\begin{array}{l}\text { - } 77 \text { patients } \\
\text { with biopsy- } \\
\text { proven } \\
\text { NAFLD }\end{array}$ & $\begin{array}{l}\text { - Lifetime alcohol consumption } \geq 24 \text { gram-years associated with } \\
\text { less advanced fibrosis (OR } 0.26 \text { [ } 95 \% \text { CI } 0.07-0.97] \text { ) compared } \\
\text { to consumption }<24 \text { gram-years } \\
\text { - Patients with abstinence }>1 \text { year had significantly higher } \\
\text { fibrosis score compared to patients with no or }<1 \text {-year } \\
\text { abstinence }(\mathrm{P}=0.04)\end{array}$ & $\begin{array}{l}\text { - Exclusion of even moderate drinkers } \\
\text { ( }>40 \text { g/week) } \\
\text { - Gram-years: grams of alcohol consumed } \\
\text { per day multiplied by years of } \\
\text { consumption }\end{array}$ \\
\hline $\begin{array}{l}\text { Dunn et al [51] } \\
2012 \text { / USA } \\
\text { Cross-sectional }\end{array}$ & $\begin{array}{l}\text { - } 582 \text { patients } \\
\text { with biopsy- } \\
\text { proven } \\
\text { NAFLD }\end{array}$ & $\begin{array}{l}\text { - Lifetime modest drinkers ( } \leq 20 \mathrm{~g} / \text { day) had lower odds of } \\
\text { having steatohepatitis, fibrosis, hepatocellular ballooning and } \\
\text { Mallory-Denk bodies in liver biopsy (OR } 0.52 \text { [ } 95 \% \text { CI } 0.36- \\
0.76], 0.56 \text { [95\%CI } 0.41-0.78], 0.62 \text { [95\%CI } 0.45-0.87 \text { ] and } 0.65 \\
\text { [95\%CI 0.43-0.97], respectively) compared to non-drinkers }\end{array}$ & $\begin{array}{l}\text { - Exclusion of heavy drinkers ( }>20 \mathrm{~g} / \\
\text { day), binge drinkers ( } \geq 6 \text { drinks on one } \\
\text { occasion } \geq \text { once monthly) and current } \\
\text { non-drinkers with a history of alcohol } \\
\text { consumption }\end{array}$ \\
\hline $\begin{array}{l}\text { Dixon et al [52] } \\
2001 / \text { Australia } \\
\text { Cross-sectional }\end{array}$ & $\begin{array}{l}\text { - } 105 \text { patients } \\
\text { with severe } \\
\text { obesity } \\
\text { - Liver biopsy } \\
\text { during } \\
\text { laparoscopy }\end{array}$ & $\begin{array}{l}\text { - Moderate }(20-100 \mathrm{~g} / \text { week }) \text { and low }(<20 \mathrm{~g} / \text { week }) \text { alcohol } \\
\text { consumption was associated with a lower incidence of } \\
\text { diabetes, NASH and presence of Mallory-Denk bodies in liver } \\
\text { biopsy (OR 0.18 [95\%CI 0.05-0.67], } 0.35 \text { [95\%CI 0.12-1] and } \\
\text { 0.16 [95\%CI 0.03-0.76], respectively) } \\
\text { - However, the effect on NASH severity was not significant when } \\
\text { adjusting for diabetes and insulin resistance }\end{array}$ & $\begin{array}{l}\text { - Patients with BMI }>35 \mathrm{~kg} / \mathrm{m}^{2} \\
\text { - Exclusion of heavy drinkers ( }>200 \mathrm{~g} / \\
\text { week) }\end{array}$ \\
\hline $\begin{array}{l}\text { Mitchell et al } \\
\text { [53] } \\
\text { 2018 / Australia } \\
\text { Cross-sectional }\end{array}$ & $\begin{array}{l}\text { - } 187 \text { patients } \\
\text { with biopsy- } \\
\text { proven } \\
\text { NAFLD }\end{array}$ & $\begin{array}{l}\text { - Modest consumption ( }<70 \mathrm{~g} / \text { week) was associated with a } \\
\text { decreased risk of advanced fibrosis (OR } 0.33 \text { [95\%CI 0.14- } \\
0.78] \text { ) compared to lifetime abstainers } \\
\text { - Exclusive wine drinkers had lower odds of advanced fibrosis } \\
\text { (OR } 0.20 \text { [95\%CI 0.06-0.69]) compared to lifetime abstainers }\end{array}$ & $\begin{array}{l}\text { - Exclusion of heavy drinkers }(>210 \\
\text { and } 140 \mathrm{~g} / \text { week for men and women, } \\
\text { respectively) } \\
\text { - Benefits are mainly associated with wine } \\
\text { drinking, not beer }\end{array}$ \\
\hline $\begin{array}{l}\text { Sookoian et al } \\
{[54]} \\
2016 / \\
\text { Argentina } \\
\text { Cross-sectional }\end{array}$ & $\begin{array}{l}\text { - } 266 \text { patients } \\
\text { with biopsy- } \\
\text { proven } \\
\text { NAFLD }\end{array}$ & $\begin{array}{l}\text { - Validation and use of a genetic variant in the alcohol } \\
\text { dehydrogenase gene, indicative of less long-term alcohol- } \\
\text { exposure }(\mathrm{P}=0.04) \\
\text { - Carriers of the genetic variant had less severe steatosis and } \\
\text { inflammation }(\mathrm{P}=0.04 \text { and } 0.015 \text {, respectively) }\end{array}$ & $\begin{array}{l}\text { - Exclusion of heavy drinkers ( }>210 \\
\text { and } 140 \mathrm{~g} / \text { week for men and women, } \\
\text { respectively) } \\
\text { - Non-significant results regarding liver } \\
\text { fibrosis }\end{array}$ \\
\hline $\begin{array}{l}\text { Ekstedt et al } \\
\text { [55] } \\
\text { 2009 / Sweden } \\
\text { Longitudinal }\end{array}$ & $\begin{array}{l}-71 \text { patients } \\
\text { with biopsy- } \\
\text { proven } \\
\text { NAFLD } \\
\text { - Median follow } \\
\text { up: } 13.8 \text { years }\end{array}$ & $\begin{array}{l}\text { - Patients with heavy episodic drinking (more than } 60 \mathrm{~g} \text { ethanol } \\
\text { in males and } 48 \mathrm{~g} \text { in females on one occasion/month) had } \\
\text { significantly higher odds of disease progression (worsening of } \geq 2 \\
\text { stages of fibrosis) (OR } 42 \text { [ } 95 \% \text { CI 5.39-329]) } \\
\text { - No association between average alcohol consumption and } \\
\text { disease progression }\end{array}$ & $\begin{array}{l}\text { - Exclusion of heavy drinkers }(>140 \mathrm{~g} / \\
\text { week), either at baseline or at follow up } \\
\text { - Higher alcohol consumption was } \\
\text { borderline insignificant regarding fibrosis } \\
\text { progression ( } \mathrm{P}=0.55 \text { OR } 1.01 \text { [ } 95 \% \mathrm{CI} \\
1-1.03 \text { ] at the multivariate model) }\end{array}$ \\
\hline $\begin{array}{l}\text { Ajmera et al } \\
\text { [56] } \\
2018 \text { / USA } \\
\text { Longitudinal }\end{array}$ & $\begin{array}{l}\text { - } 285 \text { patients } \\
\text { with } 2 \text { or more } \\
\text { liver biopsies } \\
\text { - Median follow } \\
\text { up: } 47 \text { months }\end{array}$ & $\begin{array}{l}\text { - Modest alcohol use ( } \leq 2 \text { drinks/day) was associated with } \\
\text { lower odds of NASH resolution (OR } 0.32 \text { [95\%CI 0.11-0.92]) } \\
\text { compared to non-drinkers. }\end{array}$ & $\begin{array}{l}\text { - Exclusion of moderate drinkers ( } \geq 20 \mathrm{~g} / \text { day } \\
\text { for men and } 10 \mathrm{~g} / \text { day for women), binge } \\
\text { drinkers ( } \geq 6 \text { drinks on one occasion } \geq \\
\text { once monthly) and non-drinkers with a } \\
\text { history of alcohol consumption }\end{array}$ \\
\hline $\begin{array}{l}\text { Chang et al } \\
\text { [57] } \\
2019 \text { / S. Korea } \\
\text { Longitudinal }\end{array}$ & $\begin{array}{l}\text { - } 58927 \text { patients } \\
\text { with an } \\
\text { ultrasound } \\
\text { diagnosis of } \\
\text { NAFLD } \\
\text { - Median follow } \\
\text { up: } 8.3 \text { years }\end{array}$ & $\begin{array}{l}\text { - Modest alcohol consumption (10-20 g/day) was associated } \\
\text { with worsening of noninvasive fibrosis score FIB-4, NFS and } \\
\text { APRI (HR 1.29 [95\%CI 1.18-1.40]), 1.31 [95\%CI 1.23-1.40] } \\
\text { and } 1.09 \text { [95\%CI 1.01-1.19], respectively) } \\
\text { - Light alcohol consumption (<10 g/day) was associated with } \\
\text { worsening of NFS (HR 1.09 [95\%CI [1.02-1.16]) }\end{array}$ & $\begin{array}{l}\text { - Exclusion of patients with cirrhosis or } \\
\text { intermediate/high noninvasive risks } \\
\text { score }\end{array}$ \\
\hline
\end{tabular}


Table 2 (Continued)

\begin{tabular}{|c|c|c|c|}
\hline $\begin{array}{l}\text { Study/ year/ } \\
\text { country / type }\end{array}$ & $\begin{array}{l}\text { Study } \\
\text { population }\end{array}$ & Liver-related outcomes & Comments \\
\hline $\begin{array}{l}\text { Aberg et al [58] } \\
2020 \text { / Finland } \\
\text { Longitudinal }\end{array}$ & $\begin{array}{l}\text { - } 8435 \text { patients } \\
\text { with NAFLD } \\
\text { diagnosis } \\
\text { based on Fatty } \\
\text { Liver Index } \\
>60 \\
\text { - Median follow } \\
\text { up: } 11.1 \text { years }\end{array}$ & $\begin{array}{l}\text { - Progressive increase in odds for liver-related outcomes for } \\
\text { patients with moderate to excessive alcohol consumption } \\
\text { compared to non-drinkers (HR 2.18 [95\%CI 1.05-4.53] for 10- } \\
19 \mathrm{~g} / \text { day, } 3.62 \text { [95\%CI 1.69-7.76] for } 20-29 \mathrm{~g} / \text { day, } 3.53 \text { [95\%CI } \\
1.53-8.14 \text { ] for 30-39 g/day, } 8.79 \text { [95\%CI 3.95-19.6] for } 40-49 \mathrm{~g} / \\
\text { day) } \\
\text { - Alcohol consumption <25 g with light preferential wine } \\
\text { consumption was not associated with increased odds for liver- } \\
\text { related outcomes compared to abstainers }\end{array}$ & $\begin{array}{l}\text { - Exclusion of excessive drinkers ( }>50 \mathrm{~g} / \\
\text { day) } \\
\text { - Non-significant difference between light } \\
\text { ( }<10 \text { g/day) drinkers and abstainers } \\
\text { - Liver related outcomes included } \\
\text { the development of hepatocellular } \\
\text { carcinoma }\end{array}$ \\
\hline
\end{tabular}

NAFLD, nonalcoholic fatty liver disease; OR, odds ratio; HR, hazard ratio; CI, confidence interval; NASH, nonalcoholic steatohepatitis; NFS, NAFLD fibrosis score

years, more patients who reported mild alcohol consumption (<20 g/day) developed HCC than patients abstaining from alcohol (6.5\% vs. $1.4 \%)$. This detrimental effect of alcohol was more pronounced in patients with advanced fibrosis; in this group, mild alcohol use was independently associated with the development of HCC (risk ratio 4.83, 95\%CI 1.01-23). Loomba et al evaluated the synergistic effects of alcohol and obesity on the incidence of HCC on 23,712 participants and reported similar results [61]. After a median follow up of 11.6 years, patients who consumed alcohol regularly and had BMI $>30 \mathrm{~kg} / \mathrm{m}^{2}$ had a higher incidence of HCC (HR 3.82, 95\%CI 1.94-7.52) compared with patients with neither of these factors (reference population), while patients who had BMI $>30 \mathrm{~kg} / \mathrm{m}^{2}$ and did not consume alcohol regularly had a similar incidence of HCC with the reference population.

While there are only a small number of studies investigating cancer incidence in patients with NAFLD in relation to alcohol consumption, all arrive at the same conclusion: alcohol consumption in patients with NAFLD is associated with higher odds of incident cancer, with the odds increasing in parallel with alcohol consumption. Nevertheless, the lower the consumption, the weaker the association, and more studies are needed to provide data regarding light or modest alcohol consumption to justify this association. Studies investigating the effect of alcohol consumption on cancer development in patients with NAFLD are outlined in Table 3.

\section{Is alcohol associated with better cardiovascular outcomes in patients with NAFLD?}

Given the association of NAFLD with increased cardiovascular risk, a number of studies evaluated the effects of alcohol intake on cardiovascular morbidity. In the abovementioned study by Aberg et al, patients with NAFLD who were consuming alcohol $<50 \mathrm{~g} /$ day had a lower risk for cardiovascular disease compared with abstainers (HR compared with abstainers ranging from 0.6 , 95\%CI 0.37-0.96 in patients consuming $40-49 \mathrm{~g} /$ day to $0.78,95 \% \mathrm{CI} 0.64-0.95$ in those consuming $0-9 \mathrm{~g} /$ day) [58]. This effect was even more pronounced in patients mainly consuming wine. In a study by Sinn et al in 2280 men in South Korea diagnosed with
NAFLD using ultrasound, 1797 were modest drinkers $(<20 \mathrm{~g}$ alcohol/day) and the rest did not consume any alcohol [62]. The prevalence of carotid plaques and carotid artery stenosis, surrogate markers for cardiovascular disease, was lower in the former (OR 0.74, 95\%CI 0.6-0.92, and OR 0.62, 95\%CI 0.43-0.9, respectively) after adjustment for age, smoking and MetS [62]. In contrast, in a recent study by VanWagner et al in 570 patients with NAFLD diagnosed by computed tomography, moderate alcohol consumption ( $\leq 14$ standards drinks/week for women and $\leq 21$ standard drinks/week for men) was not independently associated with the incidence of hypertension, dyslipidemia and diabetes, or with differences in measurements of coronary artery calcification, E/A ratio and global longitudinal strain after a follow up of 25 years, compared to abstainers [63].

While there is only a small number of studies regarding cardiovascular outcomes, their results imply that patients with NAFLD enjoy the same positive cardiovascular outcomes as the general population regarding moderate alcohol consumption. Notably, wine consumption seems to be the key to positive cardiovascular outcomes. Studies investigating the effect of alcohol consumption on cardiovascular outcomes in patients with NAFLD are summarized in Table 4.

\section{Does alcohol consumption impact all-cause mortality in patients with NAFLD?}

Given that alcohol consumption appears to exert different effects on the significant causes of death in patients with NAFLD (i.e., increased risk for liver-related death and lower risk for cardiovascular mortality), a limited number of studies evaluated the overall effect of moderate alcohol consumption on all-cause mortality in this population. Aberg et al reported that alcohol consumption $<10$ g/day was independently associated with lower all-cause mortality compared with nondrinkers during a follow up of 11.1 years (HR $0.79,95 \% \mathrm{CI}$ 0.66-0.95) [58]. There was no effect of alcohol consumption between 10-50 g/day. A similar study by Younossi et al showed that only excessive alcohol consumption ( $>3$ drinks/day) was independently associated with higher overall mortality (HR 1.79, 95\%CI 1.21-2.66) compared to non-excessive consumption after 20 years of mean follow up [64]. Notably, there was no difference in terms of mortality between non- 
Table 3 Studies investigating the effect of alcohol consumption on the development of cancer in patients with NAFLD

\begin{tabular}{|c|c|c|c|}
\hline $\begin{array}{l}\text { Study/ year/ } \\
\text { country / type }\end{array}$ & Study population & Cancer-related outcomes & Comments \\
\hline $\begin{array}{l}\text { Aberg et al } \\
{[58]} \\
2020 / \text { Finland } \\
\text { Longitudinal }\end{array}$ & $\begin{array}{l}\text { - } 8435 \text { patients with } \\
\text { NAFLD diagnosis based } \\
\text { on Fatty Liver Index }>60 \\
\text { - Median follow up: } 11.1 \\
\text { years }\end{array}$ & $\begin{array}{l}\text { - Progressive increase in odds for development of cancer } \\
\text { for patients with heavy to excessive alcohol consumption } \\
\text { compared to non-drinkers (HR } 1.58 \text { [ } 95 \% \text { CI } 1.08-2.32 \text { ] } \\
\text { for } 30-39 \mathrm{~g} / \text { day, } 1.75 \text { [ } 95 \% \text { CI } 1.1-2.79 \text { ] for } 40-49 \mathrm{~g} / \text { day) }\end{array}$ & $\begin{array}{l}\text { - Exclusion of excessive drinkers } \\
(>50 \mathrm{~g} / \text { day }) \\
\text { - Non-significant difference between } \\
\text { light and moderate }(<30 \mathrm{~g} / \text { day }) \\
\text { drinkers and abstainers } \\
\text { - HCC was included in liver-related } \\
\text { outcomes }\end{array}$ \\
\hline $\begin{array}{l}\text { Ascha et al } \\
{[67]} \\
2010 \text { / USA } \\
\text { Longitudinal }\end{array}$ & $\begin{array}{l}\text { - } 195 \text { patients with } \\
\text { decompensated cirrhosis } \\
\text { with biopsy-proven } \\
\text { NASH or cryptogenic } \\
\text { cirrhosis with metabolic } \\
\text { syndrome } \\
\text { - Median follow up: } 3.2 \\
\text { years }\end{array}$ & $\begin{array}{l}\text { - Patients with any lifetime alcohol consumption were } \\
\text { more likely to develop (HCC compared to abstainers } \\
\text { (HR 3.6 [95\%CI 1.5-8.3]) } \\
\text { - Social drinkers ( } \leq 2 \text { drinks/day) were more likely to } \\
\text { develop HCC compared to abstainers ( } \mathrm{P}=0.001 \text { ) }\end{array}$ & $\begin{array}{l}\text { - Included heavy drinkers and } \\
\text { binge drinkers } \\
\text { - Social drinker definition was } \\
\text { equivalent to moderate and binge } \\
\text { drinker } \\
\text { - Data from a transplantation clinic } \\
\text { - Histologic confirmation on } 59 \% \\
\text { of HCC patients }\end{array}$ \\
\hline $\begin{array}{l}\text { Kimura et al } \\
\text { [59] } \\
\text { 2018 / Japan } \\
\text { Longitudinal }\end{array}$ & $\begin{array}{l}\text { - } 301 \text { patients with biopsy- } \\
\text { proven NAFLD } \\
\text { - Median follow up: } 6 \\
\text { years }\end{array}$ & $\begin{array}{l}\text { - HCC incidence was higher in light drinking group } \\
(<20 \mathrm{~g} / \text { day) compared to the non-drinkers (6.5\% vs. } \\
1.4 \%, \mathrm{P}=0.02) \\
\text { - Light drinkers had a marginally non-significant higher } \\
\text { risk of developing HCC compared to non-drinkers (RR } \\
4.43 \text { [ } 95 \% \mathrm{CI} 0.88-22.4], \mathrm{P}=0.07) \\
\text { - In the severe fibrosis group (F3-F4), light drinkers were } \\
\text { at significantly higher risk of developing HCC compared } \\
\text { to non-drinkers (RR } 4.83 \text { [ } 95 \% \mathrm{CI} 1.01-23], \mathrm{P}=0.04)\end{array}$ & $\begin{array}{l}\text { - Exclusion of moderate drinkers } \\
\text { ( } \geq 20 \mathrm{~g} / \text { day })\end{array}$ \\
\hline $\begin{array}{l}\text { Loomba et al } \\
{[60]} \\
2013 \text { / Taiwan } \\
\text { Longitudinal }\end{array}$ & $\begin{array}{l}\text { - } 23712 \text { participants } \\
\text { in a cancer screening } \\
\text { program } \\
\text { - Median follow up: } 11.6 \\
\text { years }\end{array}$ & $\begin{array}{l}\text { - Patients with regular alcohol consumption ( } \geq 4 \text { days/ } \\
\text { week, } \geq \text { one year), both BMI }>30 \mathrm{~kg} / \mathrm{m}^{2} \text { and BMI } \\
<30 \mathrm{~kg} / \mathrm{m}^{2} \text { were more likely to develop HCC compared } \\
\text { to non-drinkers with BMI }<30 \mathrm{~kg} / \mathrm{m}^{2} \text { (HR } 3.82 \text { [95\%CI } \\
1.94-7.52 \text { ] and } 1.46[95 \% \mathrm{CI} 1.07-1.98] \text {, respectively) } \\
\text { - There was no significant difference between patients } \\
\text { with BMI }>30 \mathrm{~kg} / \mathrm{m}^{2} \text { and no alcohol consumption and } \\
\text { non-drinkers with BMI }<30 \mathrm{~kg} / \mathrm{m}^{2}\end{array}$ & $\begin{array}{l}\text { - No exclusion criteria } \\
\text { - Alcohol consumption correlated } \\
\text { independently with HCC } \\
\text { development } \\
\text { - Higher BMI was associated with } \\
\text { risk of HCC only when paired } \\
\text { with regular alcohol consumption }\end{array}$ \\
\hline
\end{tabular}

NAFLD, nonalcoholic fatty liver disease; OR, odds ratio; HR, hazard ratio; RR, risk ratio; CI, confidence interval; NASH, nonalcoholic steatohepatitis; HCC, hepatocellular carcinoma; BMI, body mass index

Table 4 Studies investigating the effect of alcohol consumption on cardiovascular outcomes in patients with NAFLD

\begin{tabular}{|c|c|c|c|}
\hline $\begin{array}{l}\text { Study/ year/ } \\
\text { country / type }\end{array}$ & Study population & Cardiovascular outcomes & Comments \\
\hline $\begin{array}{l}\text { Aberg et al }[58] \\
2020 \text { / Finland } \\
\text { Longitudinal }\end{array}$ & $\begin{array}{l}-8435 \text { patients with } \\
\text { NAFLD diagnosis } \\
\text { based on Fatty Liver } \\
\text { Index }>60 \\
\text { - Median follow up: } \\
11.1 \text { years }\end{array}$ & $\begin{array}{l}\text { - Lower risk for cardiovascular outcomes in patients with low } \\
\text { to excessive alcohol consumption compared to non-drinkers } \\
\text { (HR 0.78 [95\%CI 0.64-0.96] for }<9 \text { g/day, } 0.78 \text { [95\%CI } 0.6 \\
2.02] \text { for } 10-19 \mathrm{~g} / \text { day, } 0.71 \text { [95\%CI 0.53-0.97] for } 20-29 \mathrm{~g} / \text { day, } \\
0.71 \text { [ } 95 \% \mathrm{CI} 0.5-1] \text { for } 30-39 \mathrm{~g} / \text { day, } 0.6 \text { [95\%CI } 0.37-0.96] \text { for } \\
40-49 \mathrm{~g} / \text { day) } \\
\text { - Wine consumption was associated with cardiovascular risk } \\
\text { reduction across all categories }\end{array}$ & $\begin{array}{l}\text { - Exclusion of excessive } \\
\text { drinkers ( }>50 \mathrm{~g} / \text { day }) \\
\text { - Beneficial effect observed } \\
\text { even in heavy drinkers }\end{array}$ \\
\hline $\begin{array}{l}\text { Sinn et al [61] } \\
2014 \text { / S. Korea } \\
\text { Cross-sectional }\end{array}$ & $\begin{array}{l}-2280 \text { men with an } \\
\text { ultrasound diagnosis } \\
\text { of NAFLD }\end{array}$ & $\begin{array}{l}\text { - Lower prevalence of carotid plaque and carotid stenosis } \\
\text { among modest drinkers (<20 g/day) compared to non- } \\
\text { drinkers (OR } 0.74 \text { [ } 95 \% \mathrm{CI} 0.6-0.92] \text { and } 0.62 \text { [ } 95 \% \mathrm{CI} 0.43 \text { - } \\
0.9] \text {, respectively) }\end{array}$ & $\begin{array}{l}\text { - Exclusion of moderate } \\
\text { drinkers ( } \geq 20 \mathrm{~g} / \text { day) patients } \\
\text { with a previous history of } \\
\text { alcohol consumption }\end{array}$ \\
\hline $\begin{array}{l}\text { VanWagner } \\
\text { et al [62] } \\
\text { 2017/ USA } \\
\text { Longitudinal }\end{array}$ & $\begin{array}{l}\text { - } 570 \text { patients with CT } \\
\text { diagnosis of NAFLD } \\
\text { - Median follow up: } 25 \\
\text { years }\end{array}$ & $\begin{array}{l}\text { - No significant difference in terms of incident hypertension, } \\
\text { dyslipidemia and diabetes or measurements of coronary } \\
\text { artery calcification, E/A ratio and global longitudinal strain, } \\
\text { according to drinking status }\end{array}$ & $\begin{array}{l}\text { Exclusion of heavy drinkers } \\
\text { (>21 and } 14 \text { drinks/week for } \\
\text { men and women, respectively) }\end{array}$ \\
\hline
\end{tabular}

NAFLD, nonalcoholic fatty liver disease; OR, odds ratio; HR, hazard ratio; CI, confidence interval; CT, computed tomography 
Table 5 Studies investigating the effect of alcohol consumption on overall mortality in patients with NAFLD

\begin{tabular}{|c|c|c|c|}
\hline $\begin{array}{l}\text { Study/ year/ } \\
\text { country / type }\end{array}$ & Study population & Outcome: overall mortality & Comments \\
\hline $\begin{array}{l}\text { Aberg et al }[58] \\
2020 / \text { Finland } \\
\text { Longitudinal }\end{array}$ & $\begin{array}{l}\text { - } 8435 \text { patients with } \\
\text { NAFLD diagnosis based } \\
\text { on Fatty Liver Index }>60 \\
\text { - Median follow up: } 11.1 \\
\text { years }\end{array}$ & $\begin{array}{l}\text { - Lower risk of all-cause death in patients with } \\
\text { low alcohol consumption compared to non- } \\
\text { drinkers (HR } 0.79 \text { [ } 95 \% \text { CI } 0.66-0.95] \text { ) } \\
\text { - Alcohol consumption }>25 \mathrm{~g} \text { with no wine } \\
\text { consumption was associated with an increased } \\
\text { risk of all-cause death compared to abstainers }\end{array}$ & $\begin{array}{l}\text { - Exclusion of excessive drinkers ( }>50 \mathrm{~g} / \\
\text { day) } \\
\text { - Beneficial effects augmented by wine } \\
\text { consumption, while harmful effects } \\
\text { observed mainly in patients not } \\
\text { consuming wine }\end{array}$ \\
\hline $\begin{array}{l}\text { Hajifathalian } \\
\text { et al [65] } \\
2019 \text { / USA } \\
\text { Prospective }\end{array}$ & $\begin{array}{l}\text { - } 4568 \text { patients with } \\
\text { NAFLD } \\
\text { - Diagnosis based on the } \\
\text { Hepatic Steatosis Index } \\
\text { - Median follow up: } 70 \\
\text { months }\end{array}$ & $\begin{array}{l}\text { - Moderate consumption ( }<1.5 \text { drinks/day) } \\
\text { associated with lower all-cause mortality } \\
\text { compared to non-drinkers (HR } 0.64 \text { [ } 95 \% \mathrm{CI} \\
0.42-0.97] \text { ) } \\
\text { - Heavy consumption ( }>1.5 \text { drinks/day) } \\
\text { associated with higher all-cause mortality } \\
\text { compared to non-drinkers (HR } 1.45 \text { [95\%CI } \\
1.01-2.1] \text { ) }\end{array}$ & $\begin{array}{l}\text { - Exclusion of patients with significant } \\
\text { alcohol use ( }>3 \text { drinks/day for males, } \\
\text { and }>2 \text { drinks/day for females) } \\
\text { - Sub-analysis: benefit of moderate } \\
\text { consumption observed only in patients } \\
\text { with FIB- } 4<1.8 \text { (HR } 0.46 \text { [ } 95 \% \text { CI } 0.26- \\
0.81] \text { ) }\end{array}$ \\
\hline $\begin{array}{l}\text { Younossi et al } \\
\text { [63] } \\
2019 \text { / USA } \\
\text { Retrospective }\end{array}$ & $\begin{array}{l}\text { - } 4264 \text { individuals with } \\
\text { ultrasound diagnosis of } \\
\text { NAFLD } \\
\text { - Mean follow up: } 20 \text { years }\end{array}$ & $\begin{array}{l}\text { - Excessive alcohol consumption ( }>3 \text { drinks/day) } \\
\text { associated with higher overall mortality (HR } \\
1.79 \text { [95\%CI 1.21-2.66]) compared to non- } \\
\text { excessive consumption }\end{array}$ & $\begin{array}{l}\text { - Significant follow-up duration, higher } \\
\text { than most studies } \\
\text { - No difference with regard to drinking } \\
\text { status (non-light-moderate-substantial) } \\
\text { of non-excessive drinkers }\end{array}$ \\
\hline
\end{tabular}

drinkers and subjects with minimal ( $<3$ drinks/week), moderate ( $>3$ drinks/week but $<2$ drinks/day) and substantial ( $>2$ but $<3$ drinks/day) alcohol use. Finally, a recent study by Hajifathalian et al evaluated all-cause mortality in 4568 patients with NAFLD diagnosed with the Hepatic Steatosis Index [65] and reported that moderate consumption of alcohol $(<1.5$ standard drinks/ day) was independently related to lower all-cause mortality (HR 0.64, 95\%CI 0.42-0.97), whereas heavy consumption (>1.5 drinks/day) was independently related with higher all-cause mortality (HR 1.45, 95\%CI 1.01-2.1), compared to non-drinkers during a median follow up of 70 months [66]. Interestingly the benefit of moderate consumption was limited in patients with a low probability of fibrosis (FIB- $4<1.8$, HR $0.46,95 \%$ CI $0.26-0.81$ ) and was not observed in those with a high probability of fibrosis. Studies investigating the effect of alcohol consumption on all-cause mortality in patients with NAFLD are highlighted in Table 5.

\section{Concluding remarks}

Alcohol consumption in patients with NAFLD is a relatively novel debate, considering that previous guidelines have consistently discouraged alcohol consumption in patients with (even mild) liver disease. There is currently a relatively small number of studies regarding this topic, with significant differences in terms of conclusions. Additionally, frequent underreporting of alcohol consumption combined with the difficulty of estimating lifetime consumption further complicates these studies [67]. These limitations, combined with the significant variations in terms of methods and outcomes between the studies included in this review, make it difficult to reach definite conclusions. Nevertheless, most of the studies support the same patterns regarding the effects of alcohol consumption on NAFLD: it appears that moderate alcohol intake is associated with a lower prevalence of NAFLD and reduced cardiovascular risk in patients with NAFLD, while even light alcohol intake appears to aggravate liver disease and increase the risk of HCC. Additionally, there are conflicting reports regarding the effect of alcohol on MetS and type 2 diabetes mellitus. While most studies support a positive effect of alcohol on the development of MetS and diabetes [26,31], a recent study focusing on NAFLD patients showed an increased incidence of diabetes in patients with light-to-moderate alcohol consumption (70-210 g/week) compared to abstainers. Therefore, maintaining a cautious approach, patients with NASH or significant liver fibrosis should be advised against consuming alcohol. On the other hand, taking into account recent data, only light alcohol consumption ( $<10 \mathrm{~g} /$ day $)$ might be permitted in patients without significant hepatic fibrosis, provided that they are carefully followed-up. This recommendation is based on the fact that no study showed significant harm from light alcohol drinking, while many studies showed significant positive effects. Future studies may shed more light on this ongoing debate, possibly challenging traditional views regarding alcohol consumption in patients with liver disease.

\section{References}

1. Younossi ZM, Koenig AB, Abdelatif D, Fazel Y, Henry L, Wymer M. Global epidemiology of nonalcoholic fatty liver disease-Metaanalytic assessment of prevalence, incidence, and outcomes. Hepatology 2016;64:73-84.

2. Marchesini G, Day CP, Dufour JF, et al; European Association for the Study of Obesity (EASO). EASL-EASD-EASO Clinical Practice 
Guidelines for the management of non-alcoholic fatty liver disease. J Hepatol 2016;64:1388-1402.

3. Papatheodoridi AM, Chrysavgis L, Koutsilieris M, Chatzigeorgiou A. The role of senescence in the development of nonalcoholic fatty liver disease and progression to nonalcoholic steatohepatitis. Hepatology 2020;71:363-374.

4. Chalasani N, Younossi Z, Lavine JE, et al. The diagnosis and management of nonalcoholic fatty liver disease: Practice guidance from the American Association for the Study of Liver Diseases. Hepatology 2018;67:328-357.

5. Niikura T, Imajo K, Ozaki A, et al. Coronary artery disease is more severe in patients with non-alcoholic steatohepatitis than fatty liver. Diagnostics (Basel) 2020;10:129.

6. Jepsen P, Vilstrup H, Mellemkjaer L, et al. Prognosis of patients with a diagnosis of fatty liver-a registry-based cohort study. Hepatogastroenterology 2003;50:2101-2104.

7. Tana C, Ballestri S, Ricci F, et al. Cardiovascular risk in nonalcoholic fatty liver disease: mechanisms and therapeutic implications. Int J Environ Res Public Health 2019;16:3104.

8. Gellert KS, Keil AP, Zeng D, et al. Reducing the population burden of coronary heart disease by modifying adiposity: estimates from the ARIC study. J Am Heart Assoc 2020;9:e012214.

9. Ruidavets JB, Ducimetière P, Evans A, et al. Patterns of alcohol consumption and ischaemic heart disease in culturally divergent countries: The prospective epidemiological study of myocardial infarction (PRIME). BMJ 2010;341:c6077.

10. Bellentani S, Saccoccio G, Costa G, et al. Drinking habits as cofactors of risk for alcohol induced liver damage. Gut 1997;41:845-850.

11. Yang J, Trépo E, Nahon P, et al. PNPLA3 and TM6SF2 variants as risk factors of hepatocellular carcinoma across various etiologies and severity of underlying liver diseases. Int J Cancer 2019;144:533-544.

12. Kwon HJ, Won YS, Park O, et al. Aldehyde dehydrogenase 2 deficiency ameliorates alcoholic fatty liver but worsens liver inflammation and fibrosis in mice. Hepatology 2014;60:146-157.

13. Rehm J, Taylor B, Mohapatra S, et al. Alcohol as a risk factor for liver cirrhosis: a systematic review and meta-analysis. Drug Alcohol Rev 2010;29:437-445.

14. Liu B, Balkwill A, Reeves G, Beral V; Million Women Study Collaborators. Body mass index and risk of liver cirrhosis in middle aged UK women: prospective study. BMJ 2010;340:c912.

15. Bunout D, Gattás V, Iturriaga H, Pérez C, Pereda T, Ugarte G. Nutritional status of alcoholic patients: its possible relationship to alcoholic liver damage. Am J Clin Nutr 1983;38:469-473.

16. Iturriaga $H$, Bunout $D$, Hirsch S, Ugarte G. Overweight as a risk factor or a predictive sign of histological liver damage in alcoholics. Am J Clin Nutr 1988;47:235-238.

17. Meier P, Seitz HK. Age, alcohol metabolism and liver disease. Curr Opin Clin Nutr Metab Care 2008;11:21-26.

18. Levy R, Catana AM, Durbin-Johnson B, Halsted CH, Medici V. Ethnic differences in presentation and severity of alcoholic liver disease. Alcohol Clin Exp Res 2015;39:566-574.

19. Singh S, Fritze G, Fang BL, et al. Inheritance of mitochondrial aldehyde dehydrogenase: genotyping in Chinese, Japanese and South Korean families reveals dominance of the mutant allele. Hum Genet 1989;83:119-121.

20. Niaura RS, Nathan PE, Frankenstein W, Shapiro AP, Brick J. Gender differences in acute psychomotor, cognitive, and pharmacokinetic response to alcohol. Addict Behav 1987;12:345-356.

21. Fulham MA, Mandrekar P. Sexual dimorphism in alcohol induced adipose inflammation relates to liver injury. PLoS One 2016;11:e0164225.

22. Buch S, Stickel F, Trépo E, et al. A genome-wide association study confirms PNPLA3 and identifies TM6SF2 and MBOAT7 as risk loci for alcohol-related cirrhosis. Nat Genet 2015;47:1443-1448.

23. Tian C, Stokowski RP, Kershenobich D, Ballinger DG, Hinds DA.
Variant in PNPLA3 is associated with alcoholic liver disease. Nat Genet 2010;42:21-23.

24. European Association for the Study of the Liver. EASL Clinical Practice Guidelines: management of alcohol-related liver disease. J Hepatol 2018;69:154-181.

25. Furuya DT, Binsack R, Machado UF. Low ethanol consumption increases insulin sensitivity in Wistar rats. Brazilian J Med Biol Res 2003;36:125-130.

26. Rimm EB, Chan J, Stampfer MJ, Colditz GA, Willett WC. Prospective study of cigarette smoking, alcohol use, and the risk of diabetes in men. BMJ 1995;310:555-559.

27. Mendeloff AI. Effect of intravenous infusions of ethanol upon estimated hepatic blood flow in man. J Clin Invest 1954;33:1298-1302.

28. Baur JA, Pearson KJ, Price NL, et al. Resveratrol improves health and survival of mice on a high-calorie diet. Nature 2006;444:337-342.

29. You M, Considine RV, Leone TC, Kelly DP, Crabb DW. Role of adiponectin in the protective action of dietary saturated fat against alcoholic fatty liver in mice. Hepatology 2005;42:568-577.

30. Nakajima T, Kamijo Y, Tanaka N, et al. Peroxisome proliferatoractivated receptor alpha protects against alcohol-induced liver damage. Hepatology 2004;40:972-980.

31. Alkerwi A, Boutsen M, Vaillant M, et al. Alcohol consumption and the prevalence of metabolic syndrome: a meta-analysis of observational studies. Atherosclerosis 2009;204:624-635.

32. Ajmera VH, Terrault NA, Harrison SA. Is moderate alcohol use in nonalcoholic fatty liver disease good or bad? A critical review. Hepatology 2017;65:2090-2099.

33. Seitz HK, Mueller S, Hellerbrand C, Liangpunsakul S. Effect of chronic alcohol consumption on the development and progression of non-alcoholic fatty liver disease (NAFLD). Hepatobiliary Surg Nutr 2015;4:147-151.

34. Yeh MM, Brunt EM. Pathological features of fatty liver disease. Vol. 147, Gastroenterology. W.B. Saunders; 2014, pp. 754-764.

35. Hayashi PH, Harrison SA, Torgerson S, Perez TA, Nochajski T, Russell M. Cognitive lifetime drinking history in nonalcoholic fatty liver disease: some cases may be alcohol related. Am J Gastroenterol 2004;99:76-81.

36. Sookoian S, Pirola CJ. Systems biology eucidates common pathogenic mechanisms between nonalcoholic and alcoholic-fatty liver disease. PLoS One 2013;8:e58895.

37. Zhu L, Baker SS, Gill C, et al. Characterization of gut microbiomes in nonalcoholic steatohepatitis (NASH) patients: a connection between endogenous alcohol and NASH. Hepatology 2013;57:601-609.

38. Long MT, Massaro JM, Hoffmann U, Benjamin EJ, Naimi TS. Alcohol use is associated with hepatic steatosis among persons with presumed nonalcoholic fatty liver disease. Clin Gastroenterol Hepatol 2020;18:1831-1841.e5.

39. Hashimoto Y, Hamaguchi M, Kojima T, et al. Modest alcohol consumption reduces the incidence of fatty liver in men: a population-based large-scale cohort study. J Gastroenterol Hepatol 2015;30:546-552.

40. Gunji T, Matsuhashi N, Sato H, et al. Light and moderate alcohol consumption significantly reduces the prevalence of fatty liver in the Japanese male population. Am J Gastroenterol 2009;104:2189-2195.

41. Hiramine $Y$, Imamura $Y$, Uto $H$, et al. Alcohol drinking patterns and the risk of fatty liver in Japanese men. J Gastroenterol 2011;46:519-528.

42. Yamada T, Fukatsu M, Suzuki S, Yoshida T, Tokudome S, Joh T. Alcohol drinking may not be a major risk factor for fatty liver in Japanese undergoing a health checkup. Dig Dis Sci 2010;55:176-182.

43. Hamaguchi M, Kojima T, Ohbora A, Takeda N, Fukui M, Kato T. Protective effect of alcohol consumption for fatty liver but not metabolic syndrome. World J Gastroenterol 2012;18:156-167.

44. Chang Y, Ryu S, Kim Y, et al. Low levels of alcohol consumption, obesity, and development of fatty liver with and without evidence of advanced fibrosis. Hepatology 2020;71:861-873. 
45. Moriya A, Iwasaki Y, Ohguchi S, et al. Alcohol consumption appears to protect against non-alcoholic fatty liver disease. Aliment Pharmacol Ther 2011;33:378-388.

46. Moriya A, Iwasaki Y, Ohguchi S, et al. Roles of alcohol consumption in fatty liver: a longitudinal study. J Hepatol 2015;62:921-927.

47. Sogabe M, Okahisa T, Taniguchi T, et al. Light alcohol consumption plays a protective role against non-alcoholic fatty liver disease in Japanese men with metabolic syndrome. Liver Int 2015;35:1707-1714.

48. Sookoian S, Castaño GO, Pirola CJ. Modest alcohol consumption decreases the risk of non-alcoholic fatty liver disease: a metaanalysis of 43175 individuals. Gut 2014;63:530-532.

49. Hagström H, Nasr P, Ekstedt M, et al. Low to moderate lifetime alcohol consumption is associated with less advanced stages of fibrosis in non-alcoholic fatty liver disease. Scand J Gastroenterol 2017;52:159-165.

50. Kwon HK, Greenson JK, Conjeevaram HS. Effect of lifetime alcohol consumption on the histological severity of non-alcoholic fatty liver disease. Liver Int 2014;34:129-135.

51. Dunn W, Sanyal AJ, Brunt EM, et al. Modest alcohol consumption is associated with decreased prevalence of steatohepatitis in patients with non-alcoholic fatty liver disease (NAFLD). J Hepatol 2012;57:384-391.

52. Dixon JB, Bhathal PS, O'Brien PE. Nonalcoholic fatty liver disease: predictors of nonalcoholic steatohepatitis and liver fibrosis in the severely obese. Gastroenterology 2001;121:91-100.

53. Mitchell T, Jeffrey GP, de Boer B, et al. Type and pattern of alcohol consumption is associated with liver fibrosis in patients with nonalcoholic fatty liver disease. Am J Gastroenterol 2018;113:1484-1493.

54. Sookoian S, Flichman D, Castaño GO, Pirola CJ. Mendelian randomisation suggests no beneficial effect of moderate alcohol consumption on the severity of nonalcoholic fatty liver disease. Aliment Pharmacol Ther 2016;44:1224-1234.

55. Ekstedt M, Franzén LE, Holmqvist M, et al. Alcohol consumption is associated with progression of hepatic fibrosis in non-alcoholic fatty liver disease. Scand J Gastroenterol 2009;44:366-374.

56. Ajmera V, Belt P, Wilson LA, et al; Nonalcoholic Steatohepatitis Clinical Research Network. Among patients with nonalcoholic fatty liver disease, modest alcohol use is associated with less improvement in histologic steatosis and steatohepatitis. Clin Gastroenterol Hepatol 2018;16:1511-1520.

57. Chang Y, Cho YK, Kim Y, et al. Nonheavy drinking and worsening of noninvasive fibrosis markers in nonalcoholic fatty liver disease: a cohort study. Hepatology 2019;69:64-75.

58. Åberg F, Puukka P, Salomaa V, et al. Risks of light and moderate alcohol use in fatty liver disease: follow-up of population cohorts. Hepatology 2020;71:835-848.

59. Ascha MS, Hanouneh IA, Lopez R, Tamimi TA, Feldstein AF, Zein NN. The incidence and risk factors of hepatocellular carcinoma in patients with nonalcoholic steatohepatitis. Hepatology 2010;51:1972-1978.

60. Kimura T, Tanaka N, Fujimori N, et al. Mild drinking habit is a risk factor for hepatocarcinogenesis in non-alcoholic fatty liver disease with advanced fibrosis. World J Gastroenterol 2018;24:1440-1450.

61. Loomba R, Yang HI, Su J, et al. Synergism between obesity and alcohol in increasing the risk of hepatocellular carcinoma: a prospective cohort study. Am J Epidemiol 2013;177:333-342.

62. Sinn DH, Gwak GY, Cho J, et al. Modest alcohol consumption and carotid plaques or carotid artery stenosis in men with nonalcoholic fatty liver disease. Atherosclerosis 2014;234:270-275.

63. VanWagner LB, Ning $\mathrm{H}$, Allen NB, et al. Alcohol use and cardiovascular disease risk in patients with nonalcoholic fatty liver disease. Gastroenterology 2017;153:1260-1272.

64. Younossi ZM, Stepanova M, Ong J, et al; Global NASH Council. Effects of alcohol consumption and metabolic syndrome on mortality in patients with nonalcoholic and alcohol-related fatty liver disease. Clin Gastroenterol Hepatol 2019;17:1625-1633.

65. Lee JH, Kim D, Kim HJ, et al. Hepatic steatosis index: a simple screening tool reflecting nonalcoholic fatty liver disease. Dig Liver Dis 2010;42:503-508.

66. Hajifathalian K, Torabi Sagvand B, McCullough AJ. Effect of alcohol consumption on survival in nonalcoholic fatty liver disease: a national prospective cohort study. Hepatology 2019;70:511-521.

67. Stockwell T, Donath S, Cooper-Stanbury M, Chikritzhs T, Catalano P, Mateo C. Under-reporting of alcohol consumption in household surveys: a comparison of quantity-frequency, graduatedfrequency and recent recall. Addiction 2004;99:1024-1033. 